\title{
Nurses' perceptions of discomforts that affect the elderly in the postoperative period
}

\author{
Percepção de enfermeiros sobre desconfortos que afetam os idosos no pós-operatório \\ Percepción de enfermeros acerca de los malestares que afectan ancianos en el \\ postoperatorio
}

Rosemary Álvares de Medeiros ${ }^{1}$, Bertha Cruz Enders ${ }^{1}$, Dândara Nayara Azevêdo Dantas ${ }^{1}$, Ana Luisa Brandão de Carvalho Lira ${ }^{1}$, Alexsandro Silva Coura ${ }^{2}$, Ana Cristina Araújo de Andrade Galvão ${ }^{1}$

This study aimed to identify the perceptions of hospital nurses about the concept of comfort and discomfort that affect the elderly in the postoperative period. Exploratory, descriptive research, conducted in May and June 2014, with 30 nurses from a university hospital in Natal, RN, Brazil. It was used a questionnaire based on Kolcaba's theory of holistic comfort. Data were analyzed using descriptive statistics. Nurses (96.7\%) conceptualized comfort as well-being. In the four contexts, physical, environmental, socio-cultural and psycho-spiritual, two or more discomforts were observed by more than $50 \%$ of the nurses. Pain (100\%), excessive noise (56.7\%), feeling of displacement of their home environment $(76.7 \%)$ and anxiety (93.3\%) were more frequent. The nurses identified discomforts that affect the elderly during postoperative period in the several contexts studied, with greater emphasis on physical discomforts, especially pain. The perception of the nurses surveyed about the concept of comfort demonstrates synonymy with well-being.

Descriptors: Aged; Surgical Procedures, Operative; Palliative Care; Intensive Care; Nursing.

Objetivou-se identificar a percepção de enfermeiros hospitalares sobre o conceito de conforto e os desconfortos que afetam idosos no período pós-operatório. Pesquisa exploratória, descritiva, realizada em maio e junho de 2014, com 30 enfermeiros de um hospital universitário em Natal, RN, Brasil. Utilizou-se questionário fundamentado na teoria de conforto holístico de Kolcaba. Os dados foram analisados por meio de estatística descritiva. Os enfermeiros (96,7\%) conceituaram conforto como bem-estar. Nos quatro contextos, físico, ambiental, sociocultural e psicoespiritual, dois ou mais desconfortos foram observados por mais de 50\% dos enfermeiros. Dor (100\%), ruídos excessivos (56,7\%), sensação de deslocamento do ambiente residencial $(76,7 \%)$ e ansiedade $(93,3 \%)$ apresentaram-se mais frequentes. Os enfermeiros identificaram desconfortos que afetam os idosos no pós-operatório na diversidade dos contextos estudados, com ênfase maior aos desconfortos físicos, em especial, a dor. A percepção dos enfermeiros investigados quanto ao conceito de conforto demonstra sinonímia com o bem-estar.

Descritores: Idoso; Procedimentos Cirúrgicos Operatórios; Cuidados Paliativos; Terapia Intensiva; Enfermagem.

El objetivo fue identificar la percepción de enfermeros acerca del concepto de confort y molestias que afectan ancianos en el postoperatorio. Estudio exploratorio, descriptivo y cuantitativo, llevado a cabo en mayo y junio 2014, con 30 enfermeros de un hospital universitario de Natal, RN, Brasil. Se utilizó un cuestionario basado en la teoría de confort de Kolcaba. Los dados fueron analizados con estadística descriptiva. Los enfermeros (96,7\%) conceptuaron confort como bien estar. En los cuatros contextos, físico, ambiental, sociocultural y psicoespiritual, dos o más molestias se observaron por más de $50 \%$ de los enfermeros. Dolor (100\%), ruido excesivo (56,7\%), sentido de desplazamiento del medio ambiente residencial (76,7\%) y ansiedad $(93,3 \%)$ fueron más frecuentes. Los enfermeros identificaron molestias que afectan ancianos en el postoperatorio en los contextos investigados, enfatizándose los malestares físicos, especialmente el dolor. Los enfermeros percibieron el concepto de confort como sinónimo del bienestar.

Descriptores: Anciano; Procedimientos Quirúrgicos Operativos; Cuidados Paliativos; Cuidados Intensivos, Enfermería.

\footnotetext{
${ }^{1}$ Universidade Federal do Rio Grande do Norte. Natal, RN, Brazil

${ }^{2}$ Universidade Estadual da Paraíba. Campina Grande, PB, Brazil.

Corresponding author: Bertha Cruz Enders

Rua Pedro Fonsra Filho, 9041, Ponta Negra, CEP: 59090-080. Natal, RN, Brazil. E-mail: bertha@ufrnet.br
} 


\section{Introduction}

The increase in the elderly's life expectancy may come together with diseases that require prolonged clinical and surgical treatments ${ }^{(1-2)}$. In surgical cases, the postoperative period may require a prolonged hospital stay ${ }^{(3)}$.

In this period, it is imperative that nurses use the sensitivity to recognize the needs of these individuals for comfort, because comfort is seen as inherent to nursing care $^{(2,4-5)}$. When nurses identify the discomforts that affect their patients, they may provide an integral and humanized care.

This situation suggests that nurses need to incorporate consciously the concept of comfort in the process of care as a nursing phenomenon that should be diagnosed, planned, implemented and assessed.

However, most studies about this phenomenon focus on identifying the levels of comfort that patients demonstrate. Nurses' perspective in this process and the concept that they have about comfort are rarely addressed. Investigations that focus on nurses often seek to identify the actions they perform to promote comfort in their care and as a result one identifies primarily measures to meet physical needs ${ }^{(6)}$ or combined with care techniques such as the administration of medicine $\mathrm{e}^{(5)}$.

The importance of knowing concepts relevant to the nursing practice, such as the concept of comfort, becomes important when one considers that human responses to health conditions constitute the raw material for nursing diagnoses ${ }^{(7)}$.

Furthermore, there were no scientific studies directly related to the phenomenon of the elderly's comfort in the postoperative period or about how nurses perceive these actions. And although some studies conducted about the actions of comfort in nursing care to seniors with other diseases ${ }^{(2)}$ show that these measures go beyond therapy, it is not observed a theoretical analysis of the results, indicating that there is gap for more knowledge about this phenomenon.

Therefore, there was the need to investigate the nurses' point of views about the comfort of the elderly during the postoperative period and to analyze this phenomenon from a theoretical perspective that focuses on the comfort of the individual as a whole, not limited to physical relief. Facing this problem, one questioned: What is nurses' conception about the concept of comfort and what are the discomforts that affect the elderly during the postoperative period?

To address these questions, one used the theoretical framework Vision for Holistic Health Care and Research $^{(5)}$. It is a middle range theory in which one assumes that nursing care includes conducting a holistic assessment of patients' comfort.

According to this theory, the comfort is conceptualized as "the experience of feeling energized as an immediate result of meeting the needs of relief, tranquility and transcendence in four contexts: physical, psycho-spiritual, sociocultural and environmen-

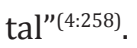

From this perspective, the need for relief refers to the experience of having a discomfort attended. The need for peace is understood as the lack of a state of contentment. Transcendence indicates the state in which someone is superior to problems or suffering, or moving to a higher state of comfort. Comfort is promoted through interventions that result in overcoming these needs related to physical, psycho-spiritual, sociocultural and environmental status of the patients ${ }^{(4)}$.

This study aimed to identify the perceptions of hospital nurses about the concept of comfort and discomforts that affect the elderly during the postoperative period.

\section{Method}

This is an exploratory, descriptive research with a quantitative approach developed by nurses at a university hospital in the city of Natal/RN, Brazil. It is also a fragment of a Master's degree dissertation entitled: Comfort of elderly patients during postoperative period from nurses' perspective. 
The study population, which totaled 30 people, was composed of nurses who worked in inpatient surgical and intensive care units of the aforementioned hospital and who provided treatment to elderly patients in the postoperative period.

One considered as inclusion criteria: having a minimum of six months of activity in the sector and being part of the working shift during the period of data collection. And as exclusion criteria: being on leave or on vacation at the time of data collection. All the 30 nurses met the specified criteria and thus formed the group of subjects in the study.

Data collection was performed by a trained researcher in the months of May and June 2014. Initially there was a prior contact with nurses, in which the objectives and purposes of the research were explained and when they were invited to participate. In case of acceptance, the Instrument of Consent was duly read and signed by the participants. There were no refusals to participate in the research.

For data collection, one used an instrument developed based on the General Comfort Questionnai$\mathrm{re}^{(4)}$; according to the International Nursing Diagnosis of NANDA 2012-2014, 'impaired comfort'(7) and the nursing interventions for this diagnosis, contained in the Nursing Interventions Classification ${ }^{(8)}$.

It is a self-explanatory questionnaire composed of four parts: I - Nurses' characterization (sex, age, religion, years after graduation, institution of graduation, additional training, time on the job, number of professional ties, work sector); II - Needs of comfort of the elderly in the postoperative period (perception about the term 'comfort', physical, environmental, socio-cultural and psychospiritual discomforts observed in the elderly during the postoperative period); III Nursing Diagnosis (nurses' knowledge about nursing diagnoses, nursing diagnoses used in the care of the elderly during postoperative period and the nursing diagnosis 'Impaired Comfort' and record in the medical record of the elderly's discomforts); IV - Nursing interventions (interventions conducted to provide comfort to the elderly patients during the postoperative period). This article focuses on parts I and II.

This questionnaire was assessed as to the aspects of organization, clarity, simplicity, readability, appropriateness of vocabulary, objectivity, accuracy, credibility, appropriateness and relevance of the contents by five nurses who have a master's degree or a doctorate in the teaching-assistance area in Brazil, in April 2014. The evaluators were selected because they have knowledge and experience in the care of elderly patients in the postoperative period. They assessed the 35 questionnaire items regarding the care aspects under evaluation by answering Yes or No to each item, giving suggestions for adjustments when necessary. Later, some items were adjusted to meet the suggestions given. No statistical validation was performed due to the limited number of evaluators.

One analyzed the variables of socio-demographic and occupational profile of participants using the descriptive statistics. The content of the concepts presented to the term "comfort" was analyzed, grouped by similarity and classified according to the physical, environmental, socio-cultural and/or psycho-spiritual context in which they fit according to the focus of the response. They were subsequently quantified in frequency and percentage. The discomforts identified by nurses in all contexts were analyzed descriptively. Data were tabulated in the free version of the Statistical Package for the Social Sciences 20.0 and presented using frequencies, percentages and measures of central tendency.

The project was approved by the Ethics Committee of the Federal University of Rio Grande do Norte, under no 25976613.7.0000.5537. All participants were informed about their voluntary participation, confidentiality of information and the right to quit the study at any time if they judged necessary and one followed the principles of Resolution No. 466/2012 of the National Health Council. 


\section{Results}

As for the socio-demographic characteristics, the majority of the participants, $90 \%(\mathrm{~N}=27)$ were females and catholic (70\%, N=21), 16.7\% (N=5) declared themselves as protestants, $6.7 \%(\mathrm{~N}=2)$, spiritualists and $6.7 \%(\mathrm{~N}=2)$ had other religions. The average age was 41.2 years old $(\min =24 ; \max =62$ years; $\sigma=10.807)$.

Regarding their professional profile, 73.3\% $(\mathrm{N}=22)$ worked in the surgical clinic sector and $26.7 \%(\mathrm{~N}=8)$ in the intensive care unit. The average of working time was 10.4 years (min. 6 months, max. 36 years. $\sigma=10$ years). A total of $86.6 \%(\mathrm{~N}=26)$ received their nursing diploma from public institutions and $13.4 \%(\mathrm{~N}=4)$ from private institutions. Out of this population, $80 \%(\mathrm{~N}=24)$ had additional training, of which $60 \%(\mathrm{~N}=18)$ were specialists, $16.7 \%(\mathrm{~N}=5)$ masters and 3.3\% (N=1) doctors. Regarding employment status, $56.7 \%(\mathrm{~N}=17)$ worked in one place and $43.3 \%$ $(\mathrm{N}=13)$ had two jobs.

The results on the classification of nurses' responses concerning their understanding about the term "comfort" are presented in Table 1.

Table 1 - Perception of nurses on the concept of comfort $(n=30)$

\begin{tabular}{lc}
\hline Concept of comfort & n (\%) \\
\hline $\begin{array}{l}\text { Physical and psycho-spiritual well-being } \\
\text { Physical, psycho-spiritual, sociocultural and environ- }\end{array}$ & $10(33.4)$ \\
mental well-being & $4(13.4)$ \\
$\begin{array}{l}\text { Physical, psycho-spiritual and environmental well- } \\
\text { being }\end{array}$ & $3(10.0)$ \\
Physical, psycho-spiritual and sociocultural well-being & $2(6.7)$ \\
Well-being & $2(6.7)$ \\
Sociocultural well-being & $2(6.7)$ \\
Physical well-being & $1(3.3)$ \\
Environmental well-being & $1(3.3)$ \\
Psycho-spiritual well-being & $1(3.3)$ \\
Physical and environmental well-being & $1(3.3)$ \\
Physical and sociocultural well-being & $1(3.3)$ \\
Sociocultural and environmental well-being & $1(3.3)$ \\
Feeling of having their needs attended & $1(3.3)$ \\
\hline
\end{tabular}

Table 1 highlights that nurses reported their understanding of the concept of comfort as a state of well-being ( $96.7 \% ; \mathrm{N}=29$ ), different from the context where they found it. The perception of comfort as physical and psycho-spiritual well-being was prominent among the others $(33.4 \% ; \mathrm{N}=10)$.

A smaller group of five nurses placed the well-being in unique contexts, sociocultural (6.7\%; $N=2$ ), psycho-spiritual $(3.3 \%, \mathrm{~N}=1)$, physical $(3.3 \%, \mathrm{~N}=1)$ and environmental $(3.3 \%, \mathrm{~N}=1)$. Two of them mentioned it merely as well-being (6.7\%; $N=2)$, without relating it to any particular contextual areas.

Examples of views expressed by nurses classified by the type of context where they existed were: physical - "feeling well - without pain" (Nurse 09); Environmental - "Sense of well-being caused by a safe and peaceful environment that meets my needs" (Nurse 01); sociocultural - "Comfort for me is a broad term, encompassing from basic human needs in humane care; it is an instrument used to promote comfort" (Nurse 11); psycho-spiritual - "Well-being; everything is related to pleasure; what is pleasant" (Nurse 14).

Other $73.4 \%(\mathrm{~N}=22)$ related the state of well-being to two or more contexts when they were asked to express their understanding of comfort. For example: "Feeling well physically, emotionally and spiritually, in a welcoming environment in which the human being is respected and valued through actions and attitudes" (Nurse 23).

One observed that, when conceptualizing comfort and well-being, nurses mentioned it in terms of a sensory condition or a way of being, a state $(\mathrm{N}=23$; $70 \%$ ). In contrast, seven (23\%) professionals conceptualized comfort as an action performed by someone else looking for an individual state of well-being in others.

Table 2 shows the relative frequency of discomforts in the four contexts observed by nurses in the elderly during the postoperative period. Among the 32 discomforts listed in the instrument, 30 were registered as present in the elderly patients during the 
postoperative period, even in different frequencies. Hectic place and unbelief about God/superior being were the discomforts not identified by nurses.

Table 2 - Discomforts identified by hospital nurses observed in elderly patients during postoperative period and the context in which they occur $(n=30)$

\begin{tabular}{lc}
\hline Discomfort and context & n (\%) \\
\hline Physical Context & $30(100.0)$ \\
Pain & $20(66.7)$ \\
Nausea & $19(63.3)$ \\
Cold & $16(53.3)$ \\
Difficulty in walking & $16(53.3)$ \\
Hunger & \\
Environmental Context & $17(56.7)$ \\
Excessive noise & $15(50.0)$ \\
Cold place & $14(46.7)$ \\
Little private place & $13(43.3)$ \\
Inadequate light & $12(40.0)$ \\
Unsafe Place & $10(33,3)$ \\
Hot place & \\
Sociocultural Context & $23(76.7)$ \\
Feeling of displacement of home environment & $16(53.3)$ \\
Less interaction with family/caregiver & $16(53.3)$ \\
Statements of unhappiness for being hospitalized & $12(40,0)$ \\
Absence of or few family visits & $9(30.0)$ \\
Difficulty of communication/being understood & $7(23.3)$ \\
Wish to have family members with them & \\
Psycho-spiritual context & $28(93.3)$ \\
Anxiety & $24(80.0)$ \\
Disorientation /delirium & $23(76.7)$ \\
Insecurity regarding recovery/prognosis & $14(46.7)$ \\
Feeling abandoned & $5(16.7)$ \\
Feeling disrespected & $8(26.6)$ \\
Apathy & \\
\hline & \\
& \\
&
\end{tabular}

All nurses (100\%) identified the physical discomfort of pain present in these patients. In the four contexts, over $50 \%$ of nurses identified two or more discomforts.

When asked about the main discomfort that affects these patients after surgery, nurses highlighted: in the physical context, pain $(80 \%$; $\mathrm{N}=240$; in the environmental context, cold place $(36.7 \% ; \mathrm{N}=11)$, and excessive noise came in second place with $26.7 \%$ $(\mathrm{N}=8)$; in the sociocultural context, sense of displacement of their home environment $(46.7 \%$; $\mathrm{N}=14)$; and in the psycho-spiritual context, anxiety $(46.7 \% \mathrm{~N}=14)$.

\section{Discussion}

The nurses were catholic women who were in the fourth decade of life. As for gender and age, the results corroborate with another study conducted in a university hospital ${ }^{(9)}$. The predominance of Catholicism in the study was already expected, since in general $65 \%$ of the population follows this religious belief, although Brazil is a secular country ${ }^{(10)}$.

Concerning professional characteristics, the nurses had years of professional experience lower than what was found in a study conducted at a teaching hospital of Porto Alegre/RS (17.14 years of work; $\sigma=6.06)^{(9)}$. A big part looked for qualification over the years of work. Similar results were obtained in another study, which found a rate of $76.7 \%$ of professionals with post-graduation degrees ${ }^{(11)}$. They only had one job.

In this study, nurses described the term "comfort" as a synonym for well-being. This term makes reference to a result of the interventions of care and to the Comfort Theory, which proposes that after the patient's holistic assessment of comfort, the needs should be identified in a multidimensional way and actions should be proposed. Then, when interventions are conducted, those individuals start to look for behaviors of well-being, divided into internal and external behaviors and peaceful death. Thus, one notices that well-being is closely related to care and to the sense of feeling taken care of and the comfort is associated to the nursing practice ${ }^{(4)}$.

In a study conducted in Brazil that addresses the concept of comfort in hospitals, $61 \%$ among clients and nurses identified comfort as synonymous with well-being ${ }^{(12)}$. Another study stated that the terms "comfort" and "care" share the same epistemological territory and have often been used in action and research in nursing in a wrong way, perhaps because they are seen as synonyms, but in fact they are not ${ }^{(13)}$.

As for the time aspect, comfort leads to an immediate situation that occurs at the moment of care when the patient is strengthened, encouraged, and 
has his discomfort relieved physically, emotionally, or much more than that, by the subject who takes care, and therefore is closely related to the outcomes of the nursing interventions ${ }^{(14)}$.

Well-being has a meaning of satisfaction, of being at peace with life, covering multiple dimensions, including self-concept, interpersonal relationships, satisfaction degree in physical and professional relationships, spiritual and physical aspects, achieved in long-term, having a close relationship with people's quality of life. And it denotes a sense of absence of symptoms or problems ${ }^{(14)}$.

Given these considerations, the results of the study are explained, in which most of the nurses interpreted comfort as well-being, since both of them have a subjective nature and are very close. Both ter$\mathrm{ms}$, directly or indirectly, depend on the interpersonal relationship between the caregiver and the one who receives care, being it closer to the nursing interventions, minimizing discomfort, or in a more complex way, as a positive balance of several outcomes of personal life $\mathrm{e}^{(14) .}$.

In this study it was seen that well-being appeared in more than one context, with the predominance of physical and psycho-spiritual contexts, followed by physical, psycho-spiritual, sociocultural and environmental well-being.

The data allowed one to identify that most nurses emphasized the physical aspect of comfort. This fact may be connected to the influence of these professionals' training, since in the hospital experience, the clinical nurses interact with patients to meet their physical needs, and from that point on, they discover other triggering nuances of multidimensional discomforts.

Through interpersonal interaction and the enhancement of skills and values that go beyond technique to meet the physical aspect of care, nurses narrow a social relationship with the patient, in search of a more humane and comprehensive care. And through this relationship they promote a mutual benefit.

In this study nurses reported pain among the main discomforts in the physical context. The measurement of this signal is always difficult for nurses because it is a subjective manifestation, since the experience of pain is unique and individual. But diagnosing it is essential to promote a humane care and, therefore, it is necessary to evaluate it regularly, and the use of scales of measurement is an effective way ${ }^{(15)}$.

During the hospital stay, many procedures contribute to the onset or exacerbation of pain in the elderly. A study in southeastern Brazil highlights moving patients in bed, conducting care and the transportation of these patients as the main factors related to this phenomenon ${ }^{(16)}$.

There are studies that describe pain as an important sign of discomfort ${ }^{(17-18)}$. A survey conducted with 70 senior citizens in postoperative period of cardiac surgery demonstrated the incidence of acute pain in about $80 \%$ in the first and second days, showing moderate intensity in this period, which decreased from the third day on $(60 \%)$, with smaller manifestations $^{(18)}$.

Estimating the intensity of pain is essential to the planning of care and the verification of the therapy ${ }^{(19)}$. Due to the subjective nature of this signal, the best way to identify it is through the patient's report itself $^{(3)}$. However, it is recognized that there are difficulties in verbal communication on the part of the elderly. Therefore, it is essential for nurses to recognize it through paralinguistic signals (facial expressions, gestures, moans, restlessness, mood changes, few activities), making appropriate interventions to alleviate them.

However, as to the main environmental discomfort that affects the elderly in the postoperative period, the cold stood out in nurses' perception. The sensitivity to temperature variations in these individuals is higher due to a lower vasoconstrictor response, a factor connected to the aging process ${ }^{(20)}$.

Added to this situation, the decrease in body metabolism, the exposure to the cold temperature in the operating room and in the intensive care unit, together with the inhibitory effects of the physiological 
mechanism of thermoregulation, including the effect of anesthetics, contribute to the onset of hypothermia and consequent discomfort, common in the first hours of the postoperative period ${ }^{(3)}$.

In this study the nurses also reported the excessive noise as a common discomfort in the elderly after surgery. It is assumed that this complaint is due to the fact that the hospital investigated is an educational institution, where in addition to the permanent service staff, students from several areas participate in the environment, which together with structural and social aspects, such as conditions to accommodate visitors, corroborate to an increased noise pollution. This fact is also shared by another study conducted in Brazil with patients in the postoperative period ${ }^{(16)}$. And it may be related to the shift changes and clinical visits of physicians and other professionals as shown by a survey at a university hospital in Campinas-SP(21).

Another factor that may contribute to the perception of excessive noise as an important inducer of environmental discomfort in the elderly is that in the intensive care unit, in addition to the characteristics above, there is also a large number of beeps from technological equipment, bringing physiological and psychological damages to patients, prolonging hospitalization and interfering with recovery. This fact was also identified in a study conducted in another Brazilian intensive care unit ${ }^{(21)}$.

In relation to the sociocultural context surrounding the hospitalization of the elderly in the postoperative period, most nurses highlighted as the main discomfort in this context the displacement of these individuals from their homes. This change was evidenced in a study as causing sadness and loneliness in the elderly due to the distance from their family members $^{(22)}$.

In addition to the statements described, a smaller experience with family members and caregivers also gained prominence in the perception of nurses as an uncomfortable cultural factor. In this universe, the family/caregiver forms a bond between the hospital and the external environment and it helps in the coping and recovery of the elderly against the stress imposed by surgery and hospitalization ${ }^{(23)}$.

Anxiety is the most common psycho-spiritual distress in the patients of this study. A study conducted in Niterói/RJ found a prevalence of the Nursing Diagnosis 'Anxiety' in 75\% of elderly patients in the postoperative period ${ }^{(24)}$. Several factors trigger the installation of this emotional state in the elderly, such as the fear of death and the prognosis, the lack of information about the disease and of solving doubts regarding the surgical procedure and situations resulting from hospitalization, confinement and social isolation by the absence of family members and even the depersonalization derived from dehumanized practices conducted by the team ${ }^{(25)}$.

\section{Conclusion}

The nurses who participated in this study identified discomforts that affect the elderly in the postoperative period in the several contexts studied, with the largest emphasis on physical discomforts, especially on pain. Their perception as to the concept of comfort demonstrates a synonymy with well-being.

The study offers a contribution to a reflection about the concept of comfort and its theoretical and philosophical perspective, also about the sensitivity of nurses to the needs of the elderly, in this care context. Furthermore, it shows the major discomforts that possibly affect these individuals in the context of the postoperative period.

Thus, the results of this research might subsidize the planning of nursing care in an individualized and humane way to these patients, with a greater focus on identifying discomforts and promoting comfort to these patients. The aim is also to contribute to the improvement of the concept of comfort in the perspective of Kolcaba's Comfort Theory.

The focus on the perception of nurses about the comfort and on the actions of comfort with the elderly in the postoperative period was a limitation of this study. An observational approach of this practice may 
have concrete results for the comfort actions conducted with this population. It is recommended, therefore, the development of investigations that seek major discomforts in all the contexts proposed by Kolcaba that afflict these individuals, so that they can complement the data presented in this study.

\section{Collaborations}

Medeiros RA, Enders BC and Dantas DNA contributed to the analysis, data interpretation, drafting of the article, critical revision and final approval of the version to be published. Coura AS, Lira ALBC and Galvão ACAA contributed to the analysis, data interpretation, important critical revision of the intellectual content and final approval of the version to be published.

\section{References}

1. Flores GC, Borges ZN, Budó MLD, Silva FM. A dádiva do cuidado: estudo qualitativo sobre o cuidado intergeracional com o idoso. Cienc Cuid Saúde. 2011; 10(3):533-40.

2. Ribeiro PCPS, Costa MAM. O conforto do doente idoso crônico em contexto hospitalar: contributos para uma revisão sistemática da literatura. Rev Enf Ref. 2012; 3(7):149-58.

3. Hagemeyer V, Gusman FT. Pós-operatório no idoso. In: Hagemeyer V, Gusman FT. Tratado de geriatria e gerontologia. $3^{\mathrm{a}}$ ed. Rio de Janeiro: Guanabara Koogan; 2011. p. 3-13.

4. Kolcaba K. Comfort. In: Peterson SJ, Bredow T, Timothy S. Middle ranges theories: application to nursing research. $2^{\mathrm{a}} \mathrm{ed}$. Philadelphia: Lippincott Wilkins; 2009. p. 254-72.

5. Pott FS, Stahlhoefer T, Felix JVC, Meier MJ. Medidas de conforto e comunicação nas ações de cuidado de enfermagem ao paciente crítico. Rev Bras Enferm. 2013; 11(2):174-9.

6. Durante ALTC, Tonini T, Armini LR. Comfort in palliative care: the know-how of nurses in general hospital. Rev Enferm UFPE online [periódico na Internet]. 2014; 8(3):530-6. Disponível em: http://www.revista.ufpe.br/revistaenfermagem/ index.php/revista/article/view/5849/pdf_4667.
7. Herdman TH. Qual é o conhecimento de enfermagem necessário para desenvolver a prática de enfermagem? Rev Eletr Enf [periódico na internet]. 2011; 13(2):161-2. Disponível em: http://www. fen.ufg.br/revista/v13/n2/v13n2a01.htm.

8. Bulechek GM, Butcher HK, Dochterman JM. Classificação das intervenções de enfermagem (NIC). 5ae ed. Rio de Janeiro: Elsevier; 2010.

9. Paranaguá TTB, Bezerra ALQ Branquinho NCSS, Souza WR, Abraão SR. Enfermeiros de um hospital universitário: evidências de um processo de seleção. Rev Enferm UERJ. 2012; 20(2):215-20.

10. Instituto Brasileiro de Geografia e Estatística. Sistema IBGE de Recuperação Automatica (SIDRA). Censo Demográfico 2010 - Tabela 1.4.1 - População residente, por situação do domicílio e sexo, segundo os grupos de religião [Internet] 2010 [citado 2014 jul 13]. Disponível em: http:// www.ibge.gov.br/home/estatistica/populacao/ censo2000/primeiros_resultados_amostra/brasil/pdf/tabela_1_4_1.pdf

11. Hilleshein EF, Lautert L. Work capacity, sociodemographic and work characteristics of nurses at a university hospital. Rev Latino-Am Enfermagem. 2012; 20(3):520-7.

12. Silva CRL, Carvalho V, Figueiredo NMA, Tonini T. Conceito de cuidado/conforto: objeto de trabalho e objeto de conhecimento de enfermagem. Cogitare Enferm. 2011; 16(2):357-60.

13. Silva CRL, Carvalho V, Figueiredo NMA, Tonini T. Conceito de cuidado/conforto: objeto de trabalho e objeto de conhecimento de enfermagem. Cogitare Enferm. 2011; 16(2):357-60.

14. Oliveira CS. Conforto e bem-estar enquanto conceitos em uso em Enfermagem. Rev Pensar Enfermagem. 2013; 17(2):2-8.

15. Bottega FH, Fontana RT. A dor como quinto sinal vital: utilização da escala de avaliação por enfermeiros de um hospital geral. Texto Contexto Enferm. 2010; 19(2):283-90.

16. Oliveira NA, Figueiredo NMA, Silva CRL, Bravo ER. Ambiente como fator de risco para clientes em pós-operatório. Rev Pesq Cuid Fundam. 2012; 4(4):2850-8.

17. Silva CCS, Vasconcelos JMB, Nóbrega MML. Dor em pacientes críticos sob a ótica de enfermeiros intensivistas: avaliação e intervenções. Rev Rene. 2011; 12(3):540-7. 
18. Xavier TT, Torres GV, Reis LA, Silva RAR, Costa IKF, Mendes FRP. Avaliação de saúde e da dor no pós-operatório de idosos submetidos à cirurgia cardíaca. Texto Contexto Enferm. 2011; 20(n. esp.):232-7.

19. Tamborelli V, Costa AF, Pereira VV, Torturella M. 0 papel da enfermagem e da fisioterapia na dor em pacientes geriátricos terminais. Rev Geriatr Gerontol. 2010; 4(3):146-53.

20. Amante LN, Slomochenski LA, Teixeira MGPN, Bertoncello KCG. Ocorrência de hiportemia não planejada em sala de recuperação anestésica. UNOPAR. Cient Ciênc Biol Saúde. 2012; 14(4):2115.

21. Heidemann AM, Cândido APL, Kosour C, Costa ARO, Dragosavac D. Influência do nível de ruídos na percepção do estresse em pacientes cardíacos. Rev Bras Ter Intensiva. 2011; 23(1):62-7.
22. Giacomini T, Wanderley KS. Compreendendo o idoso e sua vivência de internação hospitalar. Rev Kairós. 2010; 13(1):221-30.

23. Furuya RK, Birolin MM, Biazin DT, Rossi LA. A integralidade e suas interfaces no cuidado ao idoso em unidade de terapia intensiva. Rev Enferm UERJ. 2011; 19(1):158-62.

24. Bitencourt GR, Santana RF, Cavalcanti ACD, Cassiano KM. Comparação de diagnósticos de enfermagem em adultos e idosos hospitalizados no pós-operatório. Rev Eletr Enf [periódico na internet]. 2011; 13(4):604-11. Disponível em:http://www.fen.ufg.br/revista/v13/n4/ v13n4a03.htm.

25. Costa VASF, Silva SCF, Lima VCP. 0 pré-operatório e a ansiedade do paciente: a aliança entre o enfermeiro e o psicólogo. Rev SBPH. 2010; 13(2):282-98. 